\title{
Soil mesoarthropods in areas of coal mining under environmental recovery
}

\author{
Dayanna do Nascimento Machado(1), Ervandil Corrêa Costa ${ }^{(1)}$ and Leandra Pedron ${ }^{(1)}$
}

(1)Universidade Federal de Santa Maria, Departamento de Defesa Fitossanitária, Laboratório de Entomologia Florestal, Prédio 42, CEP 97105-900 Santa Maria, RS, Brazil. E-mail: dayanasmac@gmail.com, ervandilc@gmail.com, leandra_pedron@hotmail.com

\begin{abstract}
The objective of this work was to evaluate the soil mesofauna composition in non-mining and in mining areas under environmental recovery with native vegetation and forest planting, in a coalmine in Southern Brazil. Five treatments were evaluated: native vegetation in non-mining area; plantation of Acacia mearnsii in non-mining area; plantation of A. mearnsii in mining area; plantation of Eucalyptus dunnii in non-mining area; and plantation of $E$. dunnii in mining area. Four soil samples per treatment were collected monthly, during one year. The organisms were extracted using a Berlese funnel with 50-W incandescent light. A total of 23,911 organisms were collected from the soil mesofauna, which were identified and distributed into 13 taxonomic groups. The abundance of specimens was similar between treatments. The greatest diversity of taxonomic groups was found under $A$. mearnsii plantation, in the mining area, and under $E$. dunnii plantations in non-mining and mining areas, all with 13 groups. Eucalyptus dunnii and A. mearnsii help to mitigate the impact of coal mining on the diversity of the soil mesofauna taxonomic groups, since the composition of mesoarthropods is similar to that of areas that have not been directly affected by mining.
\end{abstract}

Index terms: Acacia mearnsii, Eucalyptus dunnii, anthropic area, environmental impact, forest entomology.

\section{Mesoartrópodes de solo em áreas com mineração de carvão sob recuperação ambiental}

\begin{abstract}
Resumo - O objetivo deste trabalho foi avaliar a composição da mesofauna do solo em áreas não mineradas e mineradas, sob recuperação ambiental com vegetação nativa e silvicultura, em mina de carvão mineral no Sul do Brasil. Cinco tratamentos foram avaliados: vegetação nativa em área não minerada; plantação de Acacia mearnsii em área não minerada; plantação de A. mearnsii em área minerada; plantação de Eucalyptus dunnii em área não minerada; e plantação de E. dunnii em área minerada. Durante um ano, quatro amostras de solo foram retiradas mensalmente, por tratamento. Os organismos foram extraídos com uso de funil de Berlese e luz incandescente de $50 \mathrm{~W}$. Foram coletados 23.911 organismos da mesofauna do solo, identificados e distribuídos em 13 grupos taxonômicos. A abundância de espécimes foi similar entre os tratamentos. A maior diversidade de grupos taxonômicos foi encontrada sob plantação de $A$. mearnsii, em área minerada, e nas plantações de E. dunnii em área não minerada e minerada, todas com 13 grupos. Eucalyptus dunnii e A. mearnsii auxiliam na mitigação dos impactos da mineração de carvão sobre a diversidade dos grupos taxonômicos da mesofauna do solo, pois a composição dos mesoartrópodes é semelhante à das áreas que não foram diretamente afetadas pelos efeitos da mineração.
\end{abstract}

Termos para indexação: Acacia mearnsii, Eucalyptus dunnii, área antropizada, impacto ambiental, entomologia florestal.

\section{Introduction}

The use of natural resources generates environmental impacts of greater or lesser intensity. In mining, for example, coal extraction causes environmental impacts as the exploration of natural areas changes the landscape by revolving the soil, which leads to accumulation of large volumes of waste (Silva, 2007).
Coal is an important component of the energy matrix in the world and in Brazil; however, the process of open-pit mining damages the environment, although these areas are recoverable (Reis et al., 2014). In Brazil, the state of Rio Grande do Sul accounts for $89.25 \%$ of coal reserves, followed by Santa Catarina, with $10.41 \%$; Paraná, with $0.32 \%$; and São Paulo, with $0.02 \%$. The largest coal reserve is located in the municipality of Candiota, in the southern region of 
Rio Grande do Sul, which accounts for $38 \%$ of coal production in Brazil (Aneel, 2008).

Mining at the Candiota mine is carried out in the open-pit system and the layers that overlap the coal bank are removed, together with plant coverage, which, results in large volumes of waste. The waste from mining is commonly composed of sub-surface soil horizons that were removed from the pit and rock formations (argillites or siltites), which overlap coal layers (Reis et al., 2014).

In mining areas, regardless of the environmental mitigation technique used, edaphic communities of meso- and macrofauna in the soil are adopted as tools to indicate the degree of environmental recovery. Therefore, changes in abundance, structure, and diversity reflect a greater or lesser degree of environmental recovery (Andrés \& Mateos, 2006; Menezes et al., 2009).

The soil mesofauna is represented by organisms that measure 0.2 to $2.0 \mathrm{~mm}$ and includes groups such as: Acari, Collembola, Palpigradi, Protura, Pauropoda, Diplura, Enchytraeidae, and Symphyla. These organisms play detritivorous and predatory functions in the trophic chains, in leaf litter and in the soil, acting in the biological control of pests, the incorporation of organic matter, and nutrient cycling (Melo et al., 2009). These functions make these organisms excellent indicators of soil quality (Vasconcellos et al., 2013).

The recolonization of soil fauna in recovered areas depends on the presence of edaphic organisms in surrounding areas and the ability of these populations to produce dispersing individuals (Cristescu et al., 2012). In this sense, the soil mesofauna composition in coal mining areas has been little studied in Brazil. Some studies have been conducted in the state of Santa Catarina to evaluate the effect of processes of soil recovery, after coal mining, on the soil mesofauna in the region of Lauro Müller (Oliveira Filho et al., 2014). Another study associated litter decomposition of two pioneer tree species and soil fauna, in areas recovered after surface coal mining in Southern Brazil (Frasson et al., 2016).

In the state of Rio Grande do Sul, where the largest coalmine in the country is located, there are no studies on soil mesofauna composition in mining areas, which feature native vegetation and exotic species of forest plantations, such as eucalyptus and acacia. The planting of perennial species, especially trees, can result in improvement of the chemical, physical and biological attributes of the soil (Mendonça et al., 2008a, 2008b).

The objective of this work was to evaluate the soil mesofauna composition in non-mining and in mining areas under environmental recovery with native vegetation and forest planting, in a coalmine in Southern Brazil.

\section{Materials and Methods}

The study was conducted at the Candiota mine, a coal mining area belonging to Companhia Riograndense de Mineração (CRM) (31 $33^{\prime} 20.15^{\prime \prime S}$, $53^{\circ} 42^{\prime} 27.11^{\prime \prime} \mathrm{W}$, at an altitude of $\left.170 \mathrm{~m}\right)$, located in the municipality of Candiota, in the southern region of the state of Rio Grande do Sul. The climate of the region, according to Köppen's classification, is Cfa, subtropical humid with hot summers (Alvares et al., 2013), and an average temperature of $18^{\circ} \mathrm{C}$ and annual average rainfall of $1,350 \mathrm{~mm}$. The soil is classified as an Argissolo Vermelho Eutrófico típico (Ultisol) according to the Brazilian soil classification system (Santos et al., 2006).

At the Candiota mine, five areas were selected, three non-mining and two mining ones, under environmental recovery process, which composed the five treatments ( $\mathrm{T} 1$ to $\mathrm{T} 5$ ) detailed below: $\mathrm{T} 1$, native vegetation in the mining are, with 2.20 ha, flat relief, altitude of $233 \mathrm{~m}$, located in the eastern part of the mine $\left(31^{\circ} 34^{\prime} 15.77^{\prime \prime} \mathrm{S}, 53^{\circ} 41^{\prime} 47.85^{\prime \prime} \mathrm{W}\right)$. It is characterized by no mining and by predominance of native vegetation of the pampa biome (herbaceous vegetation). However, in the area, there was the presence of annoni grass (Eragrostis plana), an exotic grass considered a weed in Rio Grande do Sul. T2, plantation of Acacia mearnsii in the mining area, with 2.89 ha, flat relief, elevation of $229 \mathrm{~m}$, located in the eastern part of the mine $\left(31^{\circ} 34^{\prime} 19.98^{\prime \prime S}\right.$, $\left.53^{\circ} 41^{\prime} 47.760^{\prime \prime} \mathrm{W}\right)$. At this location, there was no mining process and only black acacia was planted. At the beginning of the study, the stand was seven years old and the soil was covered by litter, $1 \mathrm{~cm}$ thick. T3, A. mearnsii plantation in the mining area, with $2.84 \mathrm{ha}$, flat relief, altitude of $241 \mathrm{~m}$, located in the northwestern part of the mine $\left(31^{\circ} 33^{\prime} 55.02^{\prime \prime} \mathrm{S}\right.$, $\left.53^{\circ} 43^{\prime} 20.86^{\prime \prime} \mathrm{W}\right)$, where mining occurred. However, in the coal extraction process, the material that was 
on top of the coal layers was removed, mixed, and deposited around the mining area. This material was composed of waste, namely rocks or useless minerals in the coal that are separated during processing, and by a sterile fraction composed of mineral substances that have no economic use (Silva, 2007). After mining, the material returned to the original pit, where topographical recovery of the area was done with the deposition of $30 \mathrm{~cm}$ of topsoil, fertilizer, liming, and the planting of $A$. mearnsii.

At the beginning of the collections, the stand was seven years old with the soil covered with $3-\mathrm{cm}$ thick litter, composed primarily of leaves from the trees. T4, plantation of Eucalyptus dunnii in the mining area, with 2.73 ha, flat relief, elevation of $220 \mathrm{~m}$, located in the western part of the mine $\left(31^{\circ} 34^{\prime} 15.93^{\prime \prime} \mathrm{S}\right.$, $\left.53^{\circ} 43^{\prime} 42.57^{\prime \prime W}\right)$. There was no mining process in this area, and, at the beginning of the study, the plantation was seven years old with a $5-\mathrm{cm}$ litter layer. T5, plantation of E. dunnii in the mining area, with $2.03 \mathrm{ha}$, flat relief, altitude of $227 \mathrm{~m}$, located in the northwestern part of the mine $\left(31^{\circ} 33^{\prime} 59.42^{\prime \prime} \mathrm{S}\right.$, $\left.53^{\circ} 43^{\prime} 36.31^{\prime \prime} \mathrm{W}\right)$. In this area, there was mining and, subsequently, environmental recovery occurred in the following steps: topographic recovery of the area with pit filling of the mine. Then, $30 \mathrm{~cm}$ of topsoil from other areas was added and, finally, E. dunnii seedlings were planted. Under the canopy, there was an understory with the presence of species belonging to the families Asteraceae, Gramineae, and some Pteridophytes, in addition to a $3-\mathrm{cm}$ thick layer of leaf litter.

In the surroundings of the areas studied, there was no presence of sheds. At the mine, there are containment basins and waste treatment, as well as an effective monitoring of water quality.

The mesoarthropods were sampled in a completely randomized design, between June 2014 and May 2015. Each month, four soil samples were collected per treatment at a depth of $0-10 \mathrm{~cm}$ from the soil surface, without the presence of litter, and $10 \mathrm{~m}$ distant from each other from the center of each treatment. Each sample was removed with a $10 \times 10-\mathrm{cm}$ circular probe and the volume of soil per sample was $785 \mathrm{~cm}^{3}$.

The collected material was transported to the forest entomology laboratory of Universidade Federal de Santa Maria, in the state of Rio Grande do Sul, where the samples were placed in a Berlese funnel for the extraction of edaphic soil mesofauna, which comprises the organisms with diameter between 0.2 and $2.0 \mathrm{~mm}$ (Melo et al., 2009). The samples remained inside the funnel for seven days under $50-\mathrm{W}$ incandescent light, with the temperature on soil surface at $35 \pm 5^{\circ} \mathrm{C}$. A plastic container containing 30 $\mathrm{mL}$ ethanol $70 \%(\mathrm{v} / \mathrm{v})$ was placed at the bottom of each funnel. The specimens extracted were identified at the level of order and major taxonomic groups with the aid of a stereoscopic microscope binocular. Next, they were stored in an Eppendorf tube of 1.5 $\mathrm{mL}$ containing $70 \%$ alcohol. These specimens are deposited at the forest entomology laboratory of Universidade Federal de Santa Maria.

In December 2015, ten soil subsamples were removed per treatment at $0-10-\mathrm{cm}$ depth to perform the chemical analysis. The subsamples were mixed in a 10-L plastic container and, after homogenization, a single sample of $500 \mathrm{~g}$ of soil per treatment was removed, totaling five samples. The chemical analysis was performed by the soil analysis laboratory (LAS) of the Department of Soil Sciences of Universidade Federal de Santa Maria.

For the fauna analysis, the following ecological parameters were used: abundance (total number of specimens/treatment/month), variety of taxonomic groups (total of taxonomic groups/treatment/month), and relative frequency (total specimens collected for each taxonomic group, considering the sum of all treatments). The statistical program Past (Hammer et al., 2001) was used to calculate the mesofauna diversity using the Shannon diversity index $\left(\mathrm{H}^{\prime}\right)$, obtained by the formula $\mathrm{H}^{\prime}=\sum_{\mathrm{i}-1}^{\mathrm{S}}$ piln $\mathrm{li}$, where pi is the rate of the species or group in relation to the total number of specimens found in the evaluations (Magurran, 1988); and the Pielou Evenness index, $\mathrm{e}=\mathrm{H} / \log \mathrm{S}$, where $\mathrm{H}$ corresponds to the Shannon index and $\mathrm{S}$ is the total number of groups in the community (Pielou, 1977). The Morisita-Horn Similarity (Imh) was also calculated, for which values close to or equal to zero indicate dissimilarity, and values close to or equal to one indicate similarity between the groups evaluated (Moreno, 2001); and the Jaccard index (Sj) (qualitatively: presence or absence of groups in the treatment).

The analysis of variance (Anova) was performed for the total abundance of specimens/treatment $/$ month (12 months). Abundance data were transformed by $y=(x+0.5)^{0.5}$, to meet the assumptions of normality 
and homogeneity. Subsequently, the Scott-Knott test of means was applied at 5\% probability, using the Sisvar software, version 5.6 (Universidade Federal de Lavras, Lavras, MG, Brazil).

\section{Results and Discussion}

A total of 23,911 specimens of arthropods were registered in the soil mesofauna, which were distributed in 13 taxonomic groups, belonging to six classes: Arachnida, Chilopoda, Insecta, Clitellata, Entognatha, and Malacostraca. Ten taxonomic groups were found in all treatments: Acarina, Coleoptera, Collembola, Diptera (adults), Enchytraeidae, Formicidae, Hemiptera, Isoptera, Protura, and Psocoptera (Table 1).

Treatment T4 had the largest number of specimens $(6,226)$, followed by treatments T2 $(4,831), \mathrm{T} 1(4,537)$, T5 $(4,261)$, and T3 $(4,056)$.
The abundance of specimens did not differ among the five treatments. However, the Acarina group was predominant in all of them, which presented more than 2,440 mites in the area with native vegetation, predominating specimens of the family Acaridae, suborder Astigmata, which are mostly found in places with high concentrations of decaying organic matter (Freire, 2007). Formation of litter layers with senescent materials from established plants provide a substrate for decomposer organisms to act (Frasson et al., 2016). Eucalyptus dunnii is a species already adapted to the region of study with rapid growth, greater biomass supply, and consequently greater amount of litter deposition. All of these characteristics may benefit the organisms of soil. In this site, the greater thickness of the litter layer and organic matter content (Table 2) were found compared with the other treatments, which promotes greater supply of food and shelter to a greater number of organisms.

Table 1. Edaphic mesoarthropods under native vegetation and under Acacia mearnsii and Eucalyptus dunnii plantations in mining and non-mining areas of coal, with the predominance of an Argissolo Vermelho Eutrófico típico (Ultisol), in Southern Brazil ${ }^{(1)}$.

\begin{tabular}{|c|c|c|c|c|c|c|c|}
\hline \multirow[t]{2}{*}{ Taxonomic group } & \multicolumn{5}{|c|}{ Treatment $^{(2)}$} & \multirow[t]{2}{*}{ Total } & \multirow{2}{*}{$\begin{array}{c}\text { Relative } \\
\text { frequency }(\%)^{(3)}\end{array}$} \\
\hline & $\mathrm{T} 1$ & $\mathrm{~T} 2$ & $\mathrm{~T} 3$ & $\mathrm{~T} 4$ & $\mathrm{~T} 5$ & & \\
\hline Acarina & 3,143 & 2,869 & 2,961 & 5,583 & 2,739 & 17,295 & 72.3 \\
\hline Araneae & 8 & 0 & 5 & 10 & 5 & 28 & 0.1 \\
\hline Coleoptera & 102 & 83 & 75 & 64 & 73 & 397 & 1.7 \\
\hline Collembola & 356 & 1,185 & 494 & 246 & 570 & 2,851 & 11.9 \\
\hline Diptera & 19 & 4 & 3 & 5 & 12 & 43 & 0.2 \\
\hline Enchytraeidae & 24 & 46 & 23 & 28 & 19 & 140 & 0.6 \\
\hline Formicidae & 690 & 213 & 360 & 218 & 692 & 2,173 & 9.1 \\
\hline Hemiptera & 40 & 1 & 2 & 2 & 5 & 50 & 0.2 \\
\hline Isopoda & 0 & 0 & 13 & 1 & 39 & 53 & 0.2 \\
\hline Isoptera & 8 & 6 & 6 & 4 & 17 & 41 & 0.2 \\
\hline Protura & 52 & 348 & 57 & 13 & 28 & 498 & 2.1 \\
\hline Psocoptera & 87 & 76 & 56 & 51 & 56 & 326 & 1.3 \\
\hline Thysanoptera & 8 & 0 & 1 & 1 & 6 & 16 & 0.1 \\
\hline Total of specimens & 4,537 & 4,831 & 4,056 & 6,226 & 4,261 & 23,911 & 100 \\
\hline Group diversity & 12 & 10 & 13 & 13 & 13 & - & - \\
\hline Abundance averages & $378.1 \mathrm{a}$ & $402.6 \mathrm{a}$ & $338.0 \mathrm{a}$ & $518.8 \mathrm{a}$ & $355.1 \mathrm{a}$ & - & - \\
\hline Shannon index (H') & 1.07 & 1.18 & 0.97 & 0.49 & 1.14 & - & - \\
\hline Pielou evenness $(J)$ & 0.43 & 0.51 & 0.38 & 0.19 & 0.44 & - & - \\
\hline
\end{tabular}

${ }^{(1)}$ Means followed by equal letters, in the rows, do not differ by the Scott-Knott test, at 5\% probability. ${ }^{(2)} \mathrm{T} 1$, native vegetation in the non-mining area; T2, A. mearnsii plantation in the non-mining area; T3, A. mearnsii plantation in the mining area; T4, E. dunnii plantation in the non-mining area; and T5, E. dunnii plantation in the mining area. ${ }^{(3)}$ Relative frequency of total specimens. 
The greatest diversity of taxonomic groups was found in the $A$. mearnsii plantation in the mining area (T3), in plantations of $E$. dunnii in the non-mining area (T4), and in the mining area (T4 and T5), all with 13 groups (Table 1). These areas had the thickest litter layer, composed of fresh and decaying plant material, showing that environments with expressive vegetal cover present a more diverse fauna (Canto, 1995, 1996).

The most common taxonomic groups collected in this study were: Acarina (72.3\%), Collembola (11.9\%), and Formicidae (9.1\%) (Table 1). In studies carried out in a mining area and metallurgy of lead, in the municipality of Adrianópolis, in the state of Paraná, Brazil, 23 taxa were found, among which Acarina, Collembola, and Formicidae were the most frequent groups (Barros et al., 2010). Oliveira Filho et al. (2014) reported a similar situation when assessing the effect of soil recovery processes, after coal mining on the soil mesofauna, in the municipality of Lauro Müller, in the state of Santa Catarina, Brazil. The authors found that the groups Acarina, Collembola, and Formicidae were frequent, regardless of the area and time of collection. According to Steffen et al. (2007), mites and springtails represent the largest populations of soil mesofauna.

The group Acarina was predominant in all areas. According to Sautter \& Santos (1994), Acarina is considered the first colonizers of degraded areas. This can be observed in all treatments, regardless of mining activities, because even non-mining areas can be affected by interferences in their surroundings.

Table 2. Soil analysis for each treatment, from samples taken at the $0-10-\mathrm{cm}$ soil layer, in mining and non-mining areas, with a predominance of an Argissolo Vermelho Eutrófico típico (Ultisol), in Southern Brazil.

\begin{tabular}{lccccccccc}
\hline Treatment $^{(1)}$ & $\begin{array}{c}\mathrm{pH} \\
\left(\mathrm{H}_{2} \mathrm{O}\right)\end{array}$ & $\begin{array}{c}\mathrm{OM} \\
----\left(\mathrm{g} \mathrm{kg}^{-1}\right)----\end{array}$ & Clay & $\mathrm{P}$ & $\mathrm{K}$ & $\mathrm{Cu}$ & $\mathrm{Zn}$ & $\mathrm{B}$ \\
& 5.0 & 19 & 190 & 10.1 & 176.0 & 1.5 & 8.5 & 0.3 \\
$\mathrm{~T} 1$ & 4.4 & 28 & 190 & 6.0 & 120.0 & 0.8 & 4.3 & 0.5 \\
$\mathrm{~T} 2$ & 5.2 & 28 & 230 & 2.2 & 84.0 & 1.2 & 6.6 & 0.4 \\
$\mathrm{~T} 3$ & 4.5 & 32 & 440 & 5.3 & 152.0 & 1.1 & 3.4 & 0.7 \\
$\mathrm{~T} 4$ & 4.1 & 23 & 280 & 4.5 & 84.0 & 1.3 & 1.9 & 0.3 \\
$\mathrm{~T} 5$ &
\end{tabular}

${ }^{(1)} \mathrm{T} 1$, native vegetation in the non-mining area; T2, Acacia mearnsii plantation in the non-mining area; T3, A. mearnsii plantation in the mining area; T4, Eucalyptus dunnii plantation in the non-mining area; and $\mathrm{T} 5, E$. dunnii plantation in the mining area. OM, organic matter.
Collembola was the second most frequent group, occurring with more frequency $(41.6 \%)$ of specimens in the non-mining area with $A$. mearnsii plantation (T2). The greater presence of springtails in the $A$. mearnsii plantation in the non-mining area (T2) could be linked to the strong interaction that this group has with the soil, acting on nutrient cycling, and as it has preference to feed on fungi and bacteria (Bellini \& Zeppelini, 2009). The leguminous tree species, such as Acacias, have the ability for symbiosis with mycorrhizal fungi, which helps the absorption of nutrients and water (Mendes Filho et al., 2009). Thus, the association of the species A. mearnsii with these fungi may have favored the development of the Collembola group, which multiplies and grows quickly (Antoniolli et al., 2013). However, in the $E$. dunnii plantation in the non-mining area (T4), which presented the highest percentage of soil organic matter (3.2\%) among the treatments, Collembola was the second most frequent group. The dominance of the Acarina group in this treatment may have reduced the population of springtails, as some species of mites are their predators.

The Formicidae group was the third most frequent, and the highest frequency was observed in the $E$. dunnii plantation of the mining area (T5) (31.9\%). The lowest frequency $(9.8 \%)$ of the group was found in the A. mearnsii plantation in the non-mining area (T2).

The high frequency of Formicidae in the E. dunnii and $A$. mearnsii plantations in mining areas, according to Queiroz (2013), may be related to the presence of generalist and omnivorous ants, because they are the first colonizers of damaged areas, forming a poorer community with a different composition. Therefore, after seven years of the mining process, the ants found the necessary conditions for their development and permanence in these areas. In the non-mining area with native vegetation, the second highest frequency of this group was possibly related to the non-interference of anthropic action.

Regarding total abundance, the comparison of averages showed no significant differences among the mining/recovered areas and non-mining areas, which indicates that the mining process, after seven years (except for native vegetation), did not affect the number of specimens collected (Table 1).

The greatest diversity of taxonomic groups was found in the $A$. mearnsii plantation in the non-mining

Pesq. agropec. bras., Brasília, v.52, n.12, p.1215-1222, dez. 2017 DOI: $10.1590 / \mathrm{S} 0100-204 X 2017001200010$ 
area $(\mathrm{T} 2)\left(\mathrm{H}^{\prime}=1.18\right.$ and $\left.\mathrm{J}=0.51\right)$ (Table 1), although it presented the smallest number of groups. Abundances found in the groups were well distributed, and there was no dominance of a particular group. The smallest diversity occurred in the E. dunnii plantation in the non-mining area (T4) $\left(\mathrm{H}^{\prime}=0.49\right.$ and $\left.\mathrm{J}=0.19\right)$. The greatest number of specimens and the greatest number of taxonomic groups observed in this site do not indicate that it was the most diverse among the treatments. On the contrary, the greater abundance of the Acarina group showed a non-uniform distribution of specimens among the groups. The Acaridae family was dominant among the mites and, according to Freire (2007), specimens of this family are commonly found in places with higher levels of organic matter in the soil. Therefore, there was no uniform distribution among the abundances of taxonomic groups, making this environment less diverse.

The greatest similarity by the Morisita index, among the mining/recovered areas and non-mining areas, occurred between T1 and T5 (99.3\%) (Figure 1). This similarity possibly occurred because the total abundance values were very close. In addition, the

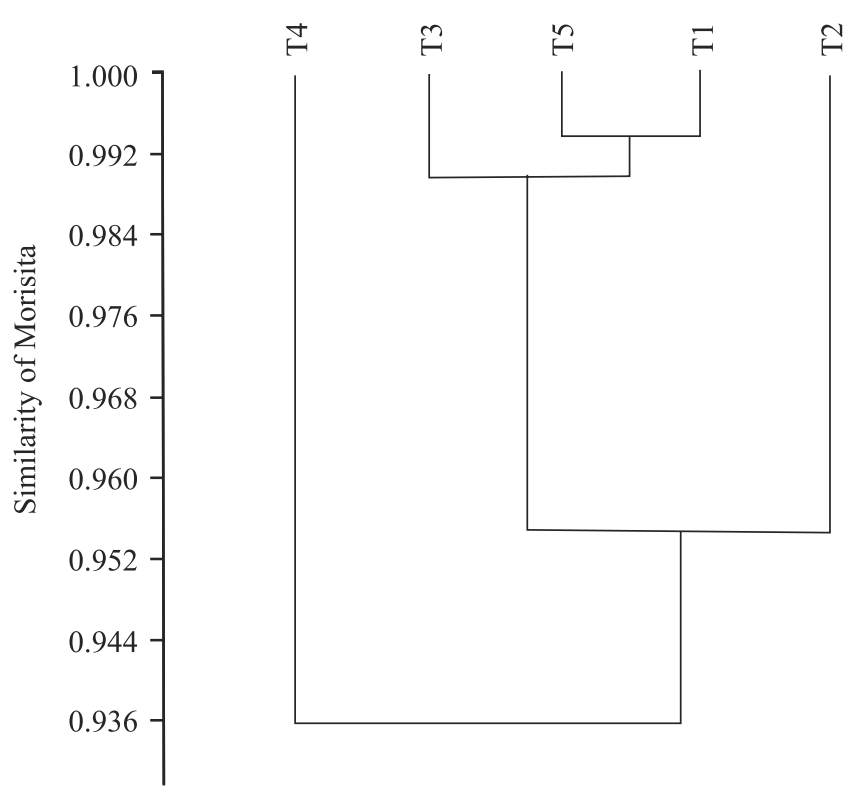

Figure 1. Dendrogram of Morisita similarity among treatments: T1, native vegetation in the non-mining area; T2, Acacia mearnsii plantation in the non-mining area; T3, A. mearnsii plantation in the mining area; T4, Eucalyptus dunnii plantation in the non-mining area; and T5, E. dunnii plantation in the mining area. vegetation found under the canopy of the E. dunnii plantation in the mining area (T5) was, in part, similar to that found in the non-mining area with native vegetation (T1). The proximity of the eucalyptus plantation with areas of native fields may have favored seed dispersal and the establishment of herbaceous species within the plantation.

By the Jaccard index, the greatest similarity between the mining/recovered areas and non-mining areas was verified among the T3, T4, and T5 (100\%) treatments (Figure 2). This similarity occurred because the soil mesofauna composition of arthropods comprised 13 taxonomic groups.

Quantitatively, $90 \%$ of the abundance of soil mesoarthropods was similar among the mining areas, which are under environmental restoration, and the non-mining areas. Qualitatively, more than $77 \%$ of the taxonomic groups were similar among the areas. This shows that the process of environmental recovery of areas under mining activities for more than seven years allowed re-establishing the diversity of soil mesofauna arthropods.

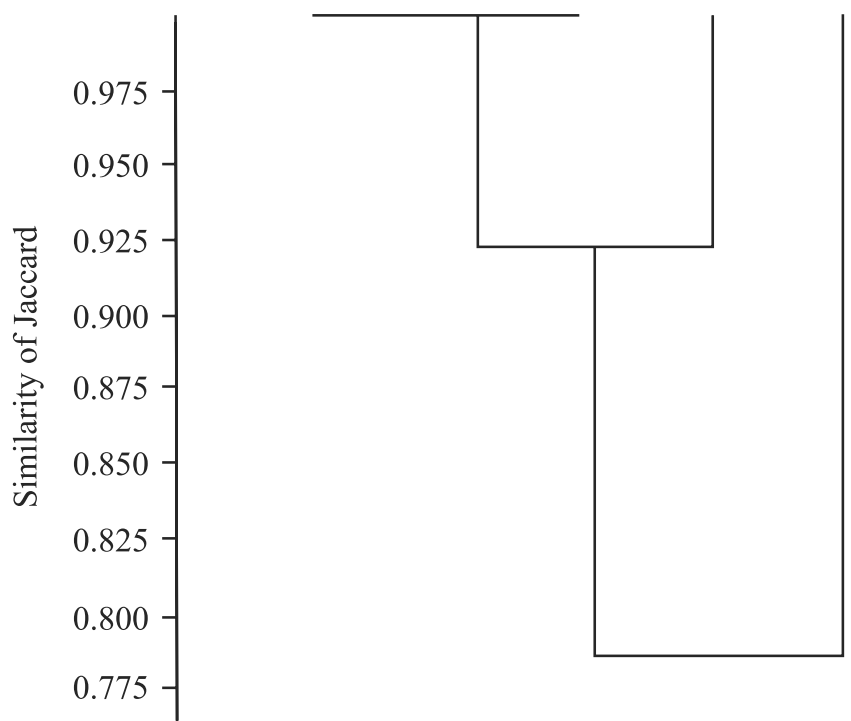

Figure 2. Dendrogram of Jaccard similarity among the treatments: T1, native vegetation in the non-mining area; $\mathrm{T} 2$, Acacia mearnsii plantation in the non-mining area; T3, A. mearnsii plantation in the mining area; T4, Eucalyptus dunnii plantation in the non-mining area; and T5, E. dunnii plantation in the mining area. 


\section{Conclusions}

1. The abundance of specimens does not differ between native vegetation in the non-mining areas, Acacia mearnsii plantation in the non-mining and mining areas, and Eucalyptus dunnii plantation in the non-mining and mining areas.

2. The greatest diversity of taxonomic groups is found under $A$. mearnsii plantation in the mining area and under E. dunnii plantations in the non-mining and mining areas, all with 13 groups.

3. Ten taxonomic groups are present in all treatments: Acarina, Coleoptera, Collembola, Diptera (adults), Enchytraeidae, Formicidae, Hemiptera, Isoptera, Protura, and Psocoptera, and the most frequent are Acarina (72.3\%), Collembola (11.9\%), and Formicidae (9.1\%).

4. The use of exotic tree species, such as E. dunnii and $A$. mearnsii, for the recovery of areas degraded by coal mining, helps mitigate impacts on the diversity of the taxonomic groups of soil mesofauna, since the composition of mesoarthropods is similar to that of areas that have not been directly affected by mining.

\section{References}

ALVARES, C.A.; STAPE, J.L.; SENTELHAS, P.C.; GONÇALVES, J.L. de M.; SPAROVEK G. Köppen's climate classification map for Brazil. Meteorologische Zeitschrift, v.22, p.711-728, 2013. DOI: 10.1127/0941-2948/2013/0507.

ANDRÉS, P.; MATEOS, E. Soil mesofaunal responses to postmining restoration treatments. Applied Soil Ecology, v.33, p.6778, 2006. DOI: 10.1016/j.apsoil.2005.08.007.

ANEEL. AGÊNCIA NACIONAL DE ENERGIA ELÉTRICA (Brasil). Atlas de energia elétrica do Brasil. Brasília: Aneel, 2008. 236p. Available at: <http://www2.aneel.gov.br/arquivos/ PDF/atlas3ed.pdf>. Accessed on: Nov. 102016.

ANTONIOLLI, Z.I.; REDIN, M.; SOUZA, E.L. de; POCOJESKI, E. Metais pesados, agrotóxicos e combustíveis: efeito na população de colêmbolos no solo. Ciência Rural, v.43, p.992-998, 2013. DOI: $10.1590 / \mathrm{S} 0103-84782013005000056$.

BARROS, Y.J.; MELO, V. de F.; SAUTTER, K.D.; BUSCHLE, B.; OLIVEIRA, E.B. de; AZEVEDO, J.C.R. de; SOUZA, L.C. de P.; KUMMER, L. Indicadores de qualidade de solos de área de mineração e metalurgia de chumbo. II - Mesofauna e plantas. Revista Brasileira de Ciência do Solo, v.34, p.1413-1426, 2010. DOI: 10.1590/S0100-06832010000400037.

BELLINI, B.C.; ZEPPELINI, D. Registros da fauna de Collembola (Arthropoda, Hexapoda) no Estado da Paraíba, Brasil. Revista Brasileira de Entomologia, v.53, p.386-390, 2009. DOI: 10.1590/ S0085-56262009000300012.
CANTO, A.C. Alterações da mesofauna do solo causadas pelo uso de cobertura com plantas leguminosas na Amazônia Central. Revista da Universidade do Amazonas. Série: Ciências Agrárias, v.4/5, p.79-94, 1995/1996.

CRISTESCU, R.H.; FRÈRE, C.; BANKS, P.B. A review of fauna in mine rehabilitation in Australia: current state and future directions. Biological Conservation, v.149, p.60-72, 2012. DOI: 10.1016/j.biocon.2012.02.003.

FRASSON, J.M. de F.; ROSADO, J.L.O.; ELIAS, S.G.; HARTERMARQUES, B. Litter decomposition of two pioneer tree species and associated soil fauna in areas reclaimed after surface coal mining in southern Brazil. Revista Brasileira de Ciência do Solo, v.40, p.e0150444, 2016. DOI: 10.1590/18069657rbcs20150444.

FREIRE, R.A.P. Ácaros predadores do Estado de São Paulo, com ênfase em Laelapidae (Acari: Mesostigmata), com potencial de uso no controle de pragas de solo. 2007. 289p. Tese (Doutorado) - Escola Superior de Agricultura Luiz de Queiroz, Piracicaba.

HAMMER, O.; HARPER, D.A.T.; RYAN, P.D. PAST: Paleontological Statistics Software Package for Education and Data Analysis. Palaeontologia Electronica, v.4, art.4, p.1-9, 2001.

MAGURRAN, A.E. Ecological diversity and its measurement. London: Croom Helm, 1988. 179p. DOI: 10.1007/978-94-0157358-0.

MELO, F.V. de; BROWN, G.G.; CONSTANTINO, R.; LOUZADA, J.N.C.; LUIZÃO, F.J.; MORAES, J.W. de; ZANETTI, R. Importância da meso e macrofauna do solo na fertilidade e como bioindicadores. Boletim Informativo da Sociedade Brasileira de Ciência do Solo, v.34, p.39-43, 2009.

MENDES FILHO, P.F.; VASCONCELLOS, R.L.F.; PAULA, A.M. de; CARDOSO, E.J.B.N. Evaluating the potential of forest species under "microbial management" for the restoration of degraded mining areas. Water, Air and Soil Pollution, v.208, p.79-89, 2009. DOI: 10.1007/s11270-009-0150-5.

MENDONÇA, A.V.R.; CARNEIRO, J.G. de A.; BARROSO, D.G.; SANTIAGO, A.R.; FREITAS, T.A.S. de; SOUZA, J.S. Desempenho de quatro espécies de Eucalyptus spp em plantios puros e consorciados com sabiá (Mimosa caesalpiniiaefolia Benth) em cava de extração de argila. Revista Árvore, v.32, p.395-405, 2008b. DOI: 10.1590/S0100-67622008000300002.

MENDONÇA, A.V.R.; CARNEIRO, J.G. de A.; GUERRA, D.B.; COUTINHO, M.P.; SOUZA, J.S. Atributos edáficos de cavas de extração de argila após cultivos puros e consorciados de Eucalyptus spp. e Mimosa caesalpiniifolia Benth (Sabiá) e quantificação da poda de sabiá. Floresta, v.38, p.431-443, 2008a. DOI: $10.5380 /$ rf.v38i3.12409.

MENEZES, C.E.G.; CORREIA, M.E.F.; PEREIRA, M.G.; BATISTA, I.; RODRIGUES, K. de M.; COUTO, W.H.; ANJOS, L.H.C. dos; OLIVEIRA, Í.P. de. Macrofauna edáfica em estádios sucessionais de Floresta Estacional Semidecidual e pastagem mista em Pinheiral (RJ). Revista Brasileira de Ciência do Solo, v.33, p.1647-1656, 2009. DOI: 10.1590/S0100-06832009000600013.

MORENO, C.E. Métodos para medir la biodiversidad. Zaragoza: Sociedad Entomológica Aragonesa, 2001. 84p. (SEA. Manuales y Tesis, v.1).

Pesq. agropec. bras., Brasília, v.52, n.12, p.1215-1222, dez. 2017 DOI: 10.1590/S0100-204X2017001200010 
OLIVEIRA FILHO, L.C.I. de; BARETTA, D.; SANTOS, J.C.P. Influência dos processos de recuperação do solo após mineração de carvão sobre a mesofauna edáfica em Lauro Müller, Santa Catarina, Brasil. Biotemas, v.27, p.69-77, 2014. DOI: 10.5007/2175-7925.2014v27n2p69.

PIELOU, E.C. Mathematical ecology. New York: J. Wiley, 1977. 385 p.

QUEIROZ, A.C.M. Formigas como indicadoras de impacto e reabilitação em áreas de mineração. 2013. 132p. Dissertação (Mestrado) - Universidade Federal de Lavras, Lavras.

REIS, D.A.; LIMA, C.L.R. de; PAULETTO, E.A. Resistência tênsil de agregados e compressibilidade de um solo construído com plantas de cobertura em área de mineração de carvão em Candiota, RS. Revista Brasileira de Ciência do Solo, v.38, p.669-678, 2014. DOI: 10.1590/S0100-06832014000200031.

SANTOS, H.G. dos; JACOMINE, P.K.T.; ANJOS, L.H.C. dos; OLIVEIRA, V.A. de; OLIVEIRA, J.B. de; COELHO, M.R.; LUMBRERAS, J.F.; CUNHA, T.J.F. (Ed.). Sistema brasileiro de classificação de solos. 2.ed. Rio de Janeiro: EMBRAPA-SPI, 2006. 306p.

SAUTTER, K.D.; SANTOS, H.R. Avaliação da estrutura da população da mesofauna edáfica, em diferentes regimes de reabilitação de um solo degradado pela mineração do xisto. Revista de Ciências Agrárias, v.13, p.31-34, 1994.

SILVA, J.P.S. Impactos ambientais causados por mineração. Revista Espaço da Sophia, ano 1, p.1-13, 2007.

STEFFEN, R.B.; ANTONIOLLI, Z.I.; STEFFEN, G.P.K. Avaliação de substratos para a reprodução de colêmbolos nativos em condições de laboratório. Ciência Florestal, v.17, p.265-269, 2007. DOI: $10.5902 / 198050981958$.

VASCONCELLOS, R.L.F.; SEGAT, J.C.; BONFIM, J.A.; BARETTA, D.; CARDOSO, E.J.B.N. Soil macrofauna as an indicator of soil quality in an undisturbed riparian forest and recovering sites of different ages. European Journal of Soil Biology, v.58, p.105-112, 2013. DOI: 10.1016/j. ejsobi.2013.07.001.

Received on October 23, 2016 and accepted on March 29, 2017 